\title{
A fair homage
}

\author{
Domingo M. Braile*
}

$\mathrm{F}$

our Brazilian cardiac surgeons who have been internationally distinguished on account of their contribution to Medicine have received an especial homage during the $18^{\text {th }}$ World Congress of the World Society of Cardio-Thoracic Surgeons, Kos (Cos) Island, Greece on April 29" 2008.

Drs. Enio Buffolo, Noedir Stolf, Randas Batista, and Ricardo Lima were chosen among other 100 physicians from all over the world, which have their name engraved in a memorial tablet placed in the marble stones supporting the monument to Hippocrates (460 BC/377 BC), at the Asclepius' Temple. According to the World Society of CardioThoracic Surgeons, the names of these practitioners "will be conserved for eternity, at the birthplace of medical profession”.

Congratulations to these outstanding Brazilian surgeons for the fair homage, which have had great repercussion in the Brazilian scientific setting. FAPESP Agency published, in May $19^{\text {th }}$ 2008, a newspaper report with Dr. Enio Buffolo regarding the subject. See below the complete newspaper report:

\section{At the heart of medicine By Fábio de Castro}

FAPESP Agency - International eminent Physicians on account of their contributions were paid solemn homage with their names engraved in marble stones supporting the Hippocrates monument (460 BC370 BC) in Kos Island, Greece, where the "father of medicine" was born. One of the names is the name of a Brazilian cardiologist, Enio Buffolo, Professor at the Federal University of São Paulo (Unifesp).

The homage was carried out during the 18th World Congress of the World Society of Cardio-Thoracic Surgeons, in The Kos island, Greece, on May 29th 2008. According to the institution, the name of the physicians awarded "will be preserved for eternity, at the birthplace of medical profession".

Full Professor of Cardiovascular Surgery and Director of the Unifesp Surgery Department, Buffolo developed, in 1982, the off-pump coronary artery bypass grafting surgery technique. "The Brazilian cardiac surgery is highly respected world-widely. It is an excellency swathe of our science, as it has been proven recently in publication from the Brazilian Academy of Sciences", says Buffolo to FAPESPAgency.

In 1983, the physician published a study in which he described the technique related to the direct offpump coronary artery bypass grafting surgery. The early outcomes accomplished with 80 patients undergoing cardiac surgery using the new technique were positive. The distinction was the procedure simplicity which used no homologous blood during the operation.

In 1996, when the Professor published the final results of his study on the Annals of Thoracic Surgery, the procedure became to be widely known and applied all over the world. The article turned to be one of the most cited articles of the Brazilian medical literature worldwide.

"During the Congress in Greece, I gave a lecture on the history and evolution of off-pump coronary artery bypass grafting surgery - which offers a less invasive alternative, by allowing to operate on a beating heart", says the professor.

In 2007, a new study that critically analyzes some 23 years' use of this surgical technique in 3,866 patients concluded that the dismissal of using the heart-lung machine (extracorporeal circuit) is an important improvement in coronary artery bypass grafting surgery (achieved by grafting a section of saphenous vein).

In the 1990s, Buffolo developed, at the Hospital São Paulo, Unifesp, the treatment of aortic aneurysms using endoprosthesis of the aneurysm and dissection of the aorta. He also collaborated in the development of a Brazilian prosthesis. His group has over a thousand patients operated on.

Buffolo graduated in 1965 at Unifesp, concluding his doctorate degree in 1973 at the same University. $\mathrm{He}$ is a member of the Brazilian Society of Cardiovascular Surgery, the European Association for Cardiothoracic Surgery, and the Brazilian College of Surgeons. Buffolo was also President of the Brazilian Society of Cardiovascular Surgery as well as the Cardiac Society of São Paulo; and former vice-president of the Brazilian Society of Cardiology.

*Editor

RBCCV/BJCVS 